\title{
THE HISTORICAL RESOURCES OF CHINA'S MODEL: RELEVANCE TO THE PRESENT ${ }^{1}$
}

\author{
MAREK HRUBEC
}

\begin{abstract}
The article focuses on the historical resources of the China's model. Understanding the model is one of necessary preconditions of an analysis of China's dynamic rise and development in recent decades. First, the article analyses the concept of historical development of multiple civilisations and modernities. It then examines the characteristics of China's old civilisation and the associated model. It ends by showing how the historical Silk Road lives on in an updated modernised global version.
\end{abstract}

Keywords: China; model; historical; civilisation; modernity

\section{Introduction}

While it is common to read what dramatic rise China has made in recent decades and how it has significantly transformed relations in the world, a deeper understanding of the underlying historical resources and principles is needed. Understanding the historical resources of the China's model is one of necessary preconditions of an analysis of China's recent unprecedented development. It enables us to understand China's reform and opening up launched in 1978 and the new global Silk Road initiated in 2013. The specific needs, interests and values that have been addressed and institutionalised in the basic types of intersubjective relations can be identified in the model. This applies to both the domestic part of the model and foreign interactions. ${ }^{2}$

In the first part of this article, I analyse the concept of historical development of multiple civilisations and modernities. In the second part, I deal with the specific characteristics of

\footnotetext{
1 The article was written within the Research Program "Global Conflicts and Local Interactions" Strategy AV21.

2 The Belt and Road Initiative, its complex relations to China's reform and opening up, and the longterm development of Chinese civilisation are analysed in my longer text which will appear in my book (Global China: Opening Up and the Belt and Road Initiative). This paper is devoted only to an analysis of the historical resources of Chinese civilisation and a brief look at how it is connected to the new Silk Road.
} 
Chinese civilisation. In the third part, I address the model of the old Chinese civilisation. In the fourth part, I briefly show how the historical Silk Road lives on in an updated, modernised version.

\section{The historical development of multiple civilisations and modernities}

In order to understand contemporary China's model and its New Silk Road, we have to identify highly complex historical developments in China that go back for centuries and, in certain respects, for more than two millennia. It is important to sketch at least the most important concepts and elements that constitute the broader picture of China's historical development as a unique civilisation. The political and economic system in China today is not the same as it was in previous millennia, but nonetheless it still exhibits what we might call historical civilisational continuity, with certain differences, as in most civilisations in the world. Civilisations are understood to be supra-social systems encompassing multiple societies and, sometimes, nations (Wang, 2017), or social historical macro-formations (Eisenstadt, 2003) with specific economic, political, and cultural spheres (Gellner, 1990). They may maintain their own specific characteristics over centuries or thousands of years, though these will evolve over time. Certain selected deeper social and civilisational patterns of institutions and activities survive across political and economic systems, often regardless of the intentions of social agents (Arnason, 2003).

Throughout history there have been multiple civilisation centres (Goody, 1996; 2006). In around $800 \mathrm{BCE}$ to $200 \mathrm{BCE}$, "civilisations of the axial age", including European and Chinese civilisations, started developing their own characteristics, some of which they have retained. Civilisations had an important influence on their own specific forms of modernisation (Eisenstadt, 2003). That is why there is no single modernity, following the Western pattern, but a plurality of modernisation pathways in different civilisations. This interpretation rejects the traditional Eurocentric theory of a colonialist uniform modernity which ascribes exceptionality to Europe and expects other civilisations to simply follow in its footsteps. Instead it holds that there are multiple modernities with their own pathways. For instance, the USSR underwent a Soviet-style modernisation in the 20th century, while a Japanese kind of modernisationhas existed since the 19th century. This is relevant to understanding China's reforms and opening up over the past 40 years as a specific and unique kind of modernisation that follows certain aspects of long-term patterns apparent in Chinese civilisation.

Nevertheless, the specific patterns that individual civilisations exhibit also evolve through internal and external interactions because civilisations, including the Chinese one, do not develop in isolation. Although there have been multiple centres throughout history, there has been almost constant intensive interactions between civilisations for centuries and thousands of years particularly via the historical Silk Road. "As the cradle of civilization, Eurasia was where civilizations coexisted and interacted." (Wang, 2017, p. 45). This dialectic of inclusion and exclusion has meant that civilisations keep their own characteristics, stemming from their foundations, and develop common (hybrid and new) characteristics in interactions with other civilisations. At the same time, various social groups create exceptions in their own civilisations and contribute to cultural complexity. 
Moreover, modernity as a whole can be viewed as a new kind of civilisation that started sometime in the middle of the second millennium and established a path-breaking civilisational change (Eisenstadt, 2003). Modernity as such exists across different civilisations, and multiple modernities usher in the new era in individual civilisations as well.

This complex explanation can be expressed briefly by stating that there are basically two models for understanding pertinent to the issue: the old reductionist model and the new complex model. The first model is the old vision that modernity existed solely in the West, follows the colonialist approach, or in general, a West-centric vision of the world with a pseudo-universalistic outlook. Other civilisations are interpreted from a prejudiced Orientalist perspective as having lower, deficient levels of development (Said, 2014). The second model is different and is based on an empathetic, respectful and intercivilisational approach that recognises the complex characteristics of social reality, which may be at various levels of development. In this model, civilisations and modernities develop their own specific characteristics and, at the same time, play a role in shaping characteristics common to particular civilisations and modernities, as well as human civilisation and global modernity as a whole.

Human civilisation has been gradually modernised and globalised by the contributions of various civilisations and modernities, and it has reached the stage of global modernity. Global modernity has modern characteristics which have a world influence. These unfortunately include problematic characteristics promoted by some modernities and civilisations, especially Western civilisation. They manifest positively and negatively in global communication, trade, cooperation, conflicts, crises, and attempts to find solutions in the United Nations, for example.

\section{The specific characteristics of Chinese civilisation}

When we compare the historical development of institutional patterns of social relations in Chinese and Western civilisations, specifically economic thinking and reality, we can identify bigger similarities in their starting points, particularly in the epochs of ancient Greece and pre-Qin (before 221 BCE). Despite their differences, they shared important characteristics with these new civilisations, viewing agriculture in a positive light and problematising the economy, for example. They experienced and valued communal institutional patterns. But in the following epochs of the Roman Empire and Qin and Han dynasties, we can identify the first "Great Divergence" (Zhang S., Zhang Y., 2018). Roman society started to favour institutional patterns linked to individual persons, while the Qin-Han period can be characterised by the evolution of the holistic equilibrium of human collectives or social groups in the community. In a number of Western countries, individualism had both positive and negative consequences. In its extreme version, it resulted in a monologic (non-dialogical) mindset and behaviour. The ruthless approach to internal and external nature - to people and to the surrounding natural environment - led to reification and alienation among people, and between people and nature. In its latent form, the first signs of this pathological development can be traced back to ancient Greece where they could be seen already in Homer's work (Hrubec, 2019). 
Of course, after the collapse of the Roman Empire, the tense individualistic characteristics of Western civilisation weakened and other problems came to the fore. Differences in economic and political thinking and practices between the West and China grew even more in the second "Great Divergence" during the industrial revolution in the second half of the 18th century (Lin, 1995; Pomeranz, 2000). Western modernity invested in innovation and its application in practice, and again accelerated the value of more aggressive trading individuals, which led to a repressive colonial system, while China maintained civilisational continuity and territorial defence against Western colonialist powers. Understandably, both individual and communal (and other) dimensions can be developed in both positive and problematic ways. I have mentioned only some examples. We cannot reduce Western and Chinese models to this issue because there were also other issues of divergence. Even so, this issue exemplifies the leading tendencies in these civilisations.

China's civilisational model prevailed for almost two thousand years until the West's domination began fully in the 19th century, after the onset of the industrial revolution. That is a short period of time when seen from the long-term historical perspective of Chinese civilisation that spans millennia. Although the period of humiliation that China had to face during the Western powers' colonialist attempts to conquer China (the Opium Wars, etc.) weakened the Chinese system and its confidence, important characteristics of the Chinese civilisation were revitalised, having survived below the surface, and helped form the institutional basis (Bell, 2016).

One of the older long-term important civilisational institutional patterns in China was the effort to balance the market and market regulation (Nolan, 2018; Pomeranz, 2000). This meant maintaining harmony between the spontaneity of the market on the one hand and the administrative corrective role of public institutions to support the prosperity and wellbeing of the people on the other. Following the reforms and opening up, and building on the long-term institutional patterns of Chinese civilisation, the Belt and Road Initiative (BRI) has been able to avoid two extremes: rejection of the market and the fetishisation of an unrestricted market. This institutional pattern cannot be taken for granted.

A comparative analysis of the consequences of the classic Soviet model of state planning and the dominance of state ownership and the version in the People's Republic of China reveals important differences (Nolan, 2018). We might ask why the successor models in the Soviet Union collapsed, while successor models in China succeeded in transforming it into a good model. Although formally, the USSR and China had almost the same politicaleconomic system in the 1970s, in practice their systems featured not only territorial modifications, but, most of all, were based on two different civilisational patterns with different historical developments. While I would not want to overestimate the importance of long-term civilisational institutional patterns - after all other medium- or short-term material and normative influences (endogenous or exogenous) may ultimately prevail, as history has sometimes shown civilisational patterns have clearly had a role to play historically.

Russia developed over more than a thousand years, but its feudal model and military control closed off its empire. Since the 16th century, the tsarist autocracy based on absolutist power has ruled Russia. Foreign invasions of Russian territory and decay in the 16th and 17th centuries hampered the country's development and consolidated serfdom, which lasted until the 1860s. The rigid social structure of patrimonialism blocked modernization and market 
potential. Peter the Great made relevant reforms and tried to Europeanise Russia from the end of the 17th century, and succeeded in building the highly cultivated and developed city of St Petersburg and its surroundings. He limited the power of the aristocrats, and introduced an administrative civil service which did not, however, actually increase social mobility. Further reform efforts, mostly inspired by the West, have only partially succeeded. Significant modernisation of the economic and state administrative system had been underway since the 1860 s but merchants were still controlled by the tsarist regime, and before the Russian revolution in 1917 industry only really developed in St Petersburg and Moscow.

Then, the system in Russia changed to reflect the political and economic philosophy of a centrally planned economy dominated by state ownership in the Soviet Union. As the economy and political system in the Soviet Union proved less effective than expected in the course of the 20th century, Gorbachev and his team pursued reforms based on the political policies of "glasnost" and "perestroika" (Gorbachev, 1987). Initially, things looked hopeful. But as became clear, it was an inconsistent mixture of Soviet and Western elements and an approach with no real historical understanding of the situation in the Soviet Union. Consequently the reforms failed and led to the system collapsing, the Soviet Union fragmenting into several states, the onset of oligarchisation, and a decline in production, trade and living standards for the majority of people living in the former Soviet republics in the 1990s, and even later in some cases (Adamishin, Schifter, 2009; Filtzer, 1994; Goldman, 1991).

After 70 years of rule, politicians and other important persons in the Soviet Union were unable to implement the reforms largely because the model had no tradition in Russia and did not fit the Russian context (Arnason, 1993, esp. chapter 4). At the same time, Russia was not prepared to follow China's example either. One key reason for this was that Russia, unlike China, did not have its own sufficient adequate historical tradition of political philosophy and policies (enabling the appropriate selection of administrators, etc.) or economic philosophy and policies (market regulation and strategic planning, etc.) from before 1917, which would have allowed it to move beyond the imperial tsarist model and develop a successful modern model (Nolan, 2018, p. 24). Nor did it in 1989-1991 either. However, it must be conceded that, in the 20th century, the Soviet Union as a state was able to make a remarkably quick transformation from a backward feudal and partially industrialised country to a modern society, building industrial infrastructure, providing free health care and education, eradicating illiteracy, constructing modern housing for its citizens, developing nuclear weapons, and becoming the first country to send a cosmonaut into space. It achieved all of this in just several decades. However, the development was mainly concentrated in specific areas, and did not extend to the web of complex social relations also required. The subsequent combination of alienated political decision-making by the latest politicians of the Soviet Union and the lack of appropriate long-term civilisational patterns of social relations compatible with the modern institutional patterns of everyday lives and communities caused the system to implode instead of successful transformation. Then, a new chapter in history began only in 2000 .

Unlike the Soviet Union, which underwent political transformation first leaving it with no time to pursue economic transformation before collapsing, China focused on economic reform. Moreover, China was in a different situation as it had continued with important aspects of governance in Chinese civilisation that survived the end of the system in 1911, 
despite aberrations in the 20th century. There is no need to analyse the thousands of years of Chinese history in detail, but several key characteristics of the historical development of the model of Chinese civilisation are worth pointing out as they remain crucial today.

\section{The old Chinese civilisation model}

After the May Fourth generation became influential in China, beginning in the 1920s, and after the revolution in 1949, the rejection of the imperial system was interpreted in China as a rejection of feudalism. This interpretation of feudalism sought to emphasise the lengthy duration of feudalism so as to highlight the struggles between social groups (Feng, 2015; Zhao, 2012). For Chinese nationalists and Communists alike, the main social agents struggling against the feudal system were peasants who were exploited by the system. In this view feudal societies were conflated with other kinds of society. However, the interpretation was rational given the system change being pursued.

Subsequently, the concept of social change evolved further. While the first interpretation linked to feudalism was inspired by intellectual influences emanating from the certain period of time of the Soviet Union, the new understanding stems from the need to differentiate more explicitly between the epochs and their main characteristics, including the new reform requirements since 1978. Strictly speaking, China's feudal system existed for a shorter period.

Here, it is necessary to distinguish the old feudal system from the system in place after 221 BCE, known for example as the "Asiatic mode of production" (Marx). Although, in the West, this term correctly drew attention to the fact that Asia was developing along different lines from Europe in the 19th century, it was still encumbered by the Orientalist underestimation of Asian methods (Dunn, 1982).

The feudal system in China (封建 fengjian) was hierarchical in structure, based on a ruler and decentralised power in local fiefdoms with vassals. The local government and administration were in the hands of the nobility (in the aristocratic positions of dukes, marquises, counts, viscounts, and barons), as implemented in the paradigmatic version under the Zhou dynasty. Enfeoffed land was not transferable by trade, which blocked development. After this old feudal system with local warlords and serfdoms became economically exhausted and collapsed politically, it was replaced by a new one (Feng, 2015).

Then, subjects were successful in their efforts to carve out more space for their economic and other activities, while emperors, drawing support from their allies in other areas, managed to unify China. The unification of China under the Qin dynasty in 221 BCE overlapped with the end of the feudal system (by contrast, the feudal system continued in Western Europe until the beginning of the modern era). Starting with the next dynasty (Han), administrators were selected on the strength of examinations (科舉 keju) of their knowledge of classical philosophy (Confucius and other classics) in the imperial court (Elman, 2000; Fairbank, 2006; Wang, 2017). Thus the new Confucian administrative system was established, and continued until the beginning of the 20th century. It is characterised by the centralisation of power by the emperor, tradable land, and a prefecture and county structure managed by administrators. 
Some remnants of the old system were preserved, but, by the Tang dynasty at the latest (from the beginning of the 7th century), it had lost all its strength, and the cultivated administrative role of governance increased. The examination system had been overhauled under the Sui dynasty (from the 6th century) and, then, refined under the Tang dynasty. It improved the quality and impartiality of bureaucrats in the state administration, from the central to local levels. This meritocratic administration was based on the rule of scholar officials (literati, 士大夫 shi dafu), who were highly educated and selected on the basis of state examinations and their ability to govern professionally. The traditional ideal of such a cultivated human being is junzi (君子), which can be loosely translated as "gentleman". Ministers and civil servants earned legitimacy by merit in education and in practice in administration, following the Confucian ethics of work that values the administrative contributions officials make to the community. The ruler and his heirs were expected to rule in harmony with the universe, with a "mandate of heaven" (天命 tianming; will of heaven) which gave them legitimacy, or a mandate of the natural order, if they were able to act justly. In the provinces, power was not in the hands of feudals, but was regulated by cultivated administrators. The market and other aspects of the economy and society were regulated according to the dialectic principle of "yin and yang" to reach "great harmony" (大同 da tong). Achieving harmony and peace is important in both China and the world, "all under heaven" (天下 tianxia).

Of course, the imperial model in China also included the non-egalitarian structure of social status, which started to become unacceptable in the modern era. In the private sphere, patriarchy dominated with unequal status between men and women, and the subjugation of other family members, much like under the traditional conservative system in the West. Unequal relations based on social status were also reproduced in the community at large. Highly hierarchical relations of subordination between the emperor, the gentry and other, lower social classes prevailed in the state sphere. Despite the establishment of a noninheritable administrative system of scholars/administrators, administrative positions were largely reproduced in the elite social group of the gentry, which, unlike the peasants and other lower social groups, had the means to support and educate its offspring. Nevertheless, even these conditions facilitated much greater social mobility than was the norm in agricultural societies, for example, in European countries. Theoretically, efforts to gain social recognition by obtaining administrative positions on the strength of examinations allowed for the partial rewarding of contributions made by individuals, families and social groups to the community and society beyond their original social status.

From the contemporary perspective, however, the traditional educational system suffered from a mechanistic way of learning. Nevertheless, it offered a holistic view of society which various modern educational systems around the world lack today because of the fragmentation of knowledge.

As in other societies in the West, positive aspects of the older system were revitalised and reformulated as parts of the new modern system (Angle, 1978). Since 1978, this has been seen particularly in the meritocratic approach in China. Deng Xioaping and his team kept to the economic and political socialist model they had in 1978, and started modifying it, using a modernised meritocratic principle for selecting students and state administrators 
and assessing workers in the countryside. Of course, the principle has been supplemented by other principles which correct the deficits of a meritocratic approach.

From 1978, China was also inspired by positive aspects of Western and other modernities in various parts of the world, including Japan. In contrast to the Anglo-Saxon model of relatively isolated citizens, the Nordic countries in Europe share with China a focus on regulating the market and other elements to achieve prosperity and meet the social needs of citizens. Although as a developing country, China does it at a lower scale of development and through its own system. This includes a combination of market and strategic planning, public and private property, and selected characteristics of China's enduring civilisation. China started finding its own "way" (道 dao), developing its own specific model of modernity and civilisation in the world family of multiple modernities and civilisations.

\section{The Silk Road and the Belt and Road}

Historically the Silk Road was an organic part of the China's long-term internal development which invented and produced goods that appealed to customers abroad. The Silk Road was a transnational network of roads over lands, seas and oceans connecting civilisations, nations, ethnic groups and religions from the Chinese to Roman empires. The Silk Road went through Eurasia, from East Asia through Central Asia, the Indian lands, Persia and Arabic lands, to South-Eastern Europe, with a detour to East and North Africa, and the surrounding seas. While silk gave the road its name, there were also many other products and creative ideas: paper, printing, the compass, gunpowder, cranes, and others, as is well known. It also had to be improved so caravans and ships were provided with protection and security. It was used for the exchange of goods and civilisational, cultural, social, philosophical, scientific, military, political and other inventions and instruments in pursuit of various aims and interests.

The Silk Road was affected also by interruptions and slowdowns from the time it was established in the 2nd century BCE. The most discussed of these is the supposed destruction of the imperial fleet in 1433 (Menzies, 2003), probably because of the imperial court's fears that merchants would become rich and the imperial court's power would be undermined. That sounds like a plausible reason. Chinese voyages were successful in gaining dominance in the South China Sea, the Indian Ocean, the Arabian Sea, and routes to Madagascar and the surrounding area.

There were other impediments. The Silk Road faced serious challenges in the 15th century, when the Ottoman Empire blocked the roads, and also when new sea routes from Europe to Asia were discovered. The process of reinstating the roads was started, but faltered in the 16th century, and came to a definite end at the beginning of the 18th century, following the decline of powerful countries around the network of roads. The Silk Road fragmented after a long era of unprecedented history. By this stage, it was impossible to renew it because Western colonial powers had carried out expeditions and established trade control in Asia. While the Silk Road was used for mutual exchanges among trade partners with positive-sum results, Western colonialism brought a zero-sum approach to trade in China. The Western powers wanted to grab a bigger share of global trade and to take over, especially in the 19th century (Pomeranz, 2000). 
The Silk Road made an enormous contribution to global history through mutual inspiring interactions between East and West. Without the Silk Road, other parts of Asia, Europe and Africa in particular would probably be different now because innovations travelled mainly from East (China, India, Persia, etc.) to West (Frankopan, 2017; Góralczyk, 2018). In part this was recently recognised symbolically. A core part of the Silk Road, particularly the network of roads along the Chang'an-Tian Shan Corridor, which stretches for five thousand kilometres in China, Kazakhstan and Kyrgyzstan, was approved as a UNESCO World Heritage site.

The Belt and Road Initiative was proposed in 2013, with the aim of building on the heritage of the Silk Road in the modern way, and following China's revolutionary transformation, i.e. the reform and opening up since 1978 (Arnason, Hrubec, 2016). It is an ambitious programme aimed at intensifying connections, communication and cooperation among countries and regions in Asia, Europe, Africa and even Latin America. It respects the five principles of coexistence and mutual cooperation: respect for sovereignty, nonaggression, non-interference in internal affairs, equality and mutual benefit, and peaceful coexistence.

The BRI introduces connectivity and makes investments in many countries, facilitating development in areas such as the economy, research and innovation, culture, and peopleto-people communication, etc. The people in these countries are aware of the results of Chinese developments to date. Not only has China become the world's largest economy by GDP (PPP), but it has also significantly increased the standard of living enjoyed by its population. In 1976, more than $82 \%$ of China's population lived in the countryside, most of them in poverty. Over the 40 years of China's reform and opening up, 800 million people have been lifted out of poverty. It is an unprecedented achievement in the history of mankind. Moreover, almost 400 million people on the east coast of China have a standard of living on a par with the average in the European Union.

The announcement of the BRI followed on from the broader framework of the Chinese Dream (中国梦 Zhongguo meng) (Xi, 2014). This concept is linked to the "great rejuvenation" of China, with chronological aims at achieving a "moderately well-off society" by 2021 (the 100th anniversary of the foundation of the CPC) and a developed society by 2049 (the 100th anniversary of the foundation of the People's Republic of China), with a milestone in between in 2035. We can see that these revolutionary transformations have domestic and some global consequences and their interconnections.

On the domestic side, various problems are tackled through more adequate regulation under the new leadership in the current turbulent global era, with stronger leadership also evident in other major countries. Domestic consumption is promoted to make the Chinese economy less dependent on Chinese exports, especially from the West, particularly following the experience of the 2008 global economic crisis and USA-China trade frictions since 2018. These problems are testing the Chinese economy and causing it to slow down. On the other side, it is pursuing its foreign policy, with new institutions supporting BRI activities (Csizmadia, 2017; Wu, 2018). For example the establishment of the Asia Infrastructure Investment Bank (AIIB) was announced in 2013, intended as a development bank for financing infrastructure in Asia and beyond. Since then, it has supplemented the activities of the World Bank and the IMF. Other projects have followed. 
The new opportunities the BRI brings have also required the countries involved to take on more responsibilities because they as well as China have to ensure Chinese investments and loans are properly evaluated and calculated. Some developing countries underestimated several projects and then found they were not able to meet their obligations (Kodituwakku, 2019). It is a challenge for China to decide how to respond in such cases. From a legal point of view, it is important for China to apply its new foreign investment law and solve disputes via an international dispute settlement mechanism when needed, and all the participants should harmonise new BRI contracts with the legal systems of countries and international agreements on the bilateral and multilateral levels. The BRI also requires appropriate legal security arrangements, as seen, for example, in the establishment of the first Chinese military base abroad, in Djibouti in the Horn of Africa, chosen as its position is ideal for monitoring and guarding the main sea routes of global trade.

Therefore, the BRI is aimed at transnational and global production, trade, and other types of cooperation, as well as domestic development, both linked to global interactions with various macro-regions around the world and the connections between China's provinces to improve, in particular, the less-developed Western provinces.

\section{Conclusion}

The historical development of Chinese civilisation has made a relevant contribution to multiple civilisations. The unique characteristics and innovations of Chinese civilisation, elements of which have helped shaped contemporary society in China to a certain extent, formed and developed during the last two millennia in particular. Although Chinese civilisation is of course much older. The specific institutional patterns of relations among people in the community are characterised by the importance of meritocracy in education and work, in keeping with principles of humanity, justice and other core values. The historical administrative system, based on these requirements to be fulfilled by scholars/ officials, enabled professional governance at various levels.

In recent decades, modernized meritocratic values have been cultivated in the institutional patterns of intersubjective relations as ideals in the spheres of family, society, the state, the economy and in relation to the world community. In order to achieve the ideal of a harmonious society, social programmes have been introduced to lift houndreds of millions of people out of poverty and to support poorer people and provinces, mainly in the west of China. There are still various problems to be overcome. These relate to both the domestic sphere and global relations. While trade disputes between the USA and China have been partially resolved, other aspects of interactions between these countries, mainly geopolitical and geoeconomic arrangements, are proving harder to tackle.

Following on from historical developments in China and from the old Silk Road in a modernized way, the Belt and Road Initiative has made a fruitful contribution to the multilateral global community, particularly in relation to meeting various local, national, regional and macro-regional needs, interests and values in different parts of the world in their various modalities and civilisations, and also in relation to human civilisation in general. Various challenges will have to be faced in order to keep relations cooperative in the future. How these are addressed remains to be seen. 


\section{References}

Adamishin, A., Schifter, R. (2009). Human Rights, Perestroika, and the End of the Cold War. Washington: US Institute of Peace.

Angle, S. C. (2012). Contemporary Confucian Political Philosophy: Toward Progressive Confucianism. Cambridge, UK: Polity Press.

Arnason, J. P. (1993). The Future that Failed: Origins and Destinies of the Soviet Model. London: Routledge.

Arnason, J. P. (2003). Civilizations in Dispute: Historical Questions and Theoretical Traditions. Leiden: Brill.

Arnason, J. P., \& Hrubec, M. (Eds.). (2016). Social Transformations and Revolutions. Edinburgh: Edinburgh University Press.

Bell, D. A. (2016). The China Model. Princeton: Princeton University Press.

Csizmadia, N. (2017). Geofusion. Mapping of the $21^{\text {st }}$ Century. Budapest: PADA.

Dunn, S. P. (1982). The Fall and Rise of the Asiatic Mode of Production. London: Routledge and Kegan Paul.

Eisenstadt, S. N. (2003). The Civilizational Dimension of Modernity. Modernity as a Distinct Civilization. In Eisenstadt, S. N. Comparative Civilizations and Multiple Modernities, II, pp. 493 518. Leiden - Boston: Brill.

Elman, B. A. (2000). A Cultural History of Civil Examinations in Late Imperial China. Berkeley: University of California Press.

Fairbank, J. K. (2006). China: A New History. Belknap Press: An Imprint of Harvard University Press.

Feng T. (2015). Society of Imperial Power: Reinterpreting China's "Feudal Society". Journal of Chinese Humanities, 1(1), 25-50.

Filtzer, D. (1994). Soviet Workers and the Collapse of Perestroika: The Soviet Labour Process and Gorbachev's Reforms, 1985-1991. Cambridge: Cambridge University Press.

Frankopan, P. (2017). The Silk Roads: A New History of the World. New York: Vintage.

Goldman, M. I. (1991). What Went Wrong With Perestroika. New York: W. W. Norton.

Gellner, E. A. (1990). Plough, Sword and Book: The Structure of Human History. University of Chicago Press.

Goodman, D. S. G. (2002). Deng Xiaoping and the Chinese Revolution: A Political Biography. London and New York: Routledge.

Goody, J. (1996). The East in the West. Cambridge: Cambridge University Press.

Goody, J. (2006). The Theft of History. Cambridge: Cambridge University Press.

Góralczyk, B. (2018). Wielki renesans. Chińska transformacja i jej konsekwencje. Warszawa: Wydawnictwo Dialog.

Gorbachev, M. (1987). Perestroika: New Thinking for Our Country and the World. Scranton, PA: Harpercollins.

Hrubec, M. (2019). Social and Environmental Conflicts or Sustainable Development? Civitas, 19(2), 281-295.

Kodituwakku, K. (2019). "Belt and Road: The View From Sri Lanka. The Sri Lankan Ambassador to China, Karunasena Kodituwakku, gives an interview.” Beijing Review, April 15, 2019.

Lin, J. Y. (1995). The Needham Puzzle: Why the Industrial Revolution Did Not Originate in China. Economic Development and Cultural Change, 43(2), 269-292.

Menzies, G. (2008). 1421: The Year China Discovered America. New York, NY: William Morrow.

Nolan, P. (2018). China and the West: Crossroads of Civilization. London and New York: Routledge.

Pomeranz, K. (2000). The Great Divergence: China, Europe, and the Making of the Modern World Economy. Princeton: Princeton University Press. 
Said, E. W. (2014). Orientalism. New York: Vintage.

Wang, M. (2017). Civilizations and its Conceptualizations in Ethnology, Social Anthropology, and Sociology. Journal of China in Comparative Perspective, 3(1), 44-71.

Wu, Z. (2018). Functional Logic of the Belt and Road Initiative: Based on a New Interpretation of Geoeconomics. SASS Studies, 12, 28-68.

Zhao, L. (2012). Feudal and feudalism in modern China. Journal of Modern Chinese History, 6(2), 198-216.

Zhang, S. \& Zhang, Y. (2018). The "Great Divergence" of Chinese and Western Economic Thoughts: Based on Comparative Studies on Economic Thoughts of the Roman and Qin-Han Period. SASS Studies, 12, 68-96.

Centre of Global Studies

Institute of Philosophy

The Czech Academy of Sciences

Jilská 1

11000 Prague 1

Czech Republic

Email: hrubec@flu.cas.cz 